\title{
A ECONOMIA SOCIAL SOLIDÁRIA E RED COMPARTE NA AMÉRICA LATINA EM TEMPOS DE PANDEMIA
}

\section{The solidary social economy and Red Comparte in Latin America in pandemic times}

\author{
Alvaro Idárraga \\ Red COMPARTE/CPAL \\ Joaci de S. Cunha \\ Universidade Católica de Salvador (UCSAL); CEAS, Salvador,
} Brasil

\section{Informações do artigo}

Recebido em 01/10/2020

Aceito em 25/11/2020

doi>: https://doi.org/10.25247/2447-861X.2020.n250.p398-428

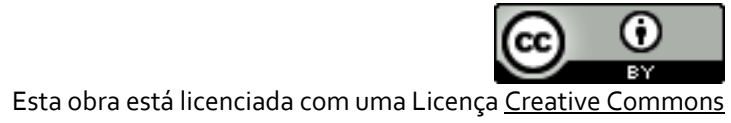
Atribuição 4.0 Internacional.

\section{Como ser citado (modelo ABNT)}

IDÁRRAGA, Alvaro; CUNHA, Joaci de S. A economia social solidária e Red Comparte na América Latina em tempos de pandemia. Cadernos do CEAS:

Revista Crítica de Humanidades. Salvador/Recife, v. 45, n. 250 , p. 398-428, maio/ago. 2020. DOI: https://doi.org/10.25247/2447-861X.2020.n250.p398-428
Resumo
O presente artigo discute a economia social solidária na América Latina a partir da experiência e dos princípios da Rede COMPARTE, abordando as iniciativas desse setor da economia popular frente à conjuntura da pandemia de Covid-19. Inicialmente, parte de uma leitura da crise sanitária inserida num contexto maior de crise estrutural de reprodução das relações e da acumulação capitalista, como pressuposto das políticas públicas adotadas por alguns governos do continente, a exemplo do Brasil, Argentina e Colômbia, frente às urgências sociais da pandemia. As iniciativas dos segmentos solidários são vistas como caminhos alternativos de ação social e de reorganização produtiva dos setores populares diante da incapacidade do capital, em crise, para incorporar amplos setores da população latino-americana à produção de bens, serviços e cuidados sociais. Assim, ações autônomas em espaços de elevados niveis de desigualdade e de desconexão com os governos podem ter evitado um número ainda maior de adoecimento e mortes. Nessa direção, as iniciativas solidárias abordadas aportam sinais de recuperação dos valores, modos de produzir e relações sociais, em geral, muito distintos daqueles produzidos pela dinâmica de mercado. Contribuem, portanto, para a reorganização da vida comunitária em outros moldes, rompendo com a subjetividade baseada em valores éticomorais egoísticos. Por essa trilha, a experiência da Rede COMPARTE reflete múltiplas expressões de economias alternativas, em vários niveis de progresso e crescimento, que podem convergir para um movimento social que transforme, mas, sobretudo, multiplique o princípio do cuidado com a vida e quiçá rompa com a lógica capitalista e sua natureza especulativo-financeira.

Palavras-Chave: Economia Solidária. Crise Capitalista. Conjuntura da Pandemia. Covid-19.

\section{Abstract}

This article discusses the social solidarity economy in Latin America based on the experience and principles of the COMPARTE Network, addressing the initiatives of this sector of the popular economy in the conjuncture of the Covid-19 pandemic. Initially, it is part of a reflection on the health crisis inserted in a larger context of structural crisis of reproduction of relations and capitalist accumulation, as a premise of the public policies adopted by some governments of the continent, such as Brazil, Argentina and Colombia, in face of the social emergencies of the pandemic. The initiatives of solidarity segments are seen as alternative ways of social action and productive reorganization of popular sectors in front of the incapacity of capital, in crisis, to incorporate broad sectors of Latin American population to the production of goods, services and social care. Thus, autonomous actions, in regions of high levels of inequality and disconnection from governments, may have avoided an even greater number of illnesses and deaths. In this perspective, the solidarity initiatives that have been approached show signs of recovery of moral values, production methods and social relations, in general, very different from those produced by market dynamics. Therefore, the solidarity initiatives contribute to the reorganization of community life in other forms, breaking with subjectivity based on egoistic ethical-moral values. Along this path, the experience of the COMPARTE Network reflects multiple expressions of alternative economies, at various levels of progress and growth, which may converge towards a social movement that transforms and, most importantly, multiplies the principle of care for life and perhaps breaks with capitalist logic and its speculative-financial nature.

Keywords: Solidarity Economy. Capitalist Crisis. Pandemic Situation. Covid-19. 


\section{Introdução}

O dilaceramento das relações e dos valores sociais, levado a cabo pela dinâmica de reprodução do capital nas atuais crises econômica, sanitária, socioambiental e política deixa certas produções fílmicas hollywoodianas com ares utópicos. Duvida? Pois bem, nestes filmes, de pouco valor artístico, mas de grande orçamento, não raro culturas e países diferentes se unem para enfrentar ameaças que vêm do espaço, de mundos estranhos, meteoros ou vírus que ameaçam a vida na terra.

Todavia, unidade de propósitos foi o que não se viu como resposta internacional à grave ameaça e ao efetivo rastro de contaminação e morte produzidas pelo SARS-Cov-2. Ao contrário de parceria global entre as potências, o que se vê são tentativas de enfraquecimento da Organização Mundial da Saúde (OMS), disputas geopolíticas reavivando o fantasma nuclear, controles neofascistas sendo aplicados ou articulados, guerras regionais em preparação; além de agravarem-se a xenofobia, o racismo, o feminicídio e a destruição ambiental. Enfim, o que vimos são diversas formas de manifestação da crise do modo de produção capitalista e das subjetividades por ele difundidas.

Com esta resposta afirmamos o pressuposto que dá lastro ao presente texto, mas que não define o seu tema. A conjuntura geral, ainda que seja o seu horizonte temático, não é, em sentido estrito, diretamente o seu objeto. O foco da análise aqui são os sinais de recuperação dos valores, modos de produzir e relações sociais, em geral, muito distintos daqueles produzidos pela dinâmica capitalista e sua sociedade em crises múltiplas.

As experiências que dão base às discussões aqui realizadas são formas de produzir alternativas em experimentação, acompanhadas pelo trabalho de um coletivo de centros sociais e organizações produtivas camponesas em atividade por toda a América Latina, que constituem a Rede COMPARTE.

Mais especificamente, a rede COMPARTE é uma comunidade de aprendizagem e ação composta por 16 centros sociais, distribuídos por dois programas em 11 países da América Latina e uma instituição (ALBOAN) na Espanha. Desde 2011, a COMPARTE tem centrado a sua ação na qualificação de experiências econômicas produtivas, sustentáveis e expansíveis, presentes em territórios rurais e urbanos em benefício de comunidades e territórios excluídos e marginalizados pelo sistema econômico e político vigente. A expansividade ou ampliação de escala dessas iniciativas depende de muitas variáveis, uma 
delas é a própria crise da economia capitalista, cujas relações de produção são cada vez mais incapazes de absorver o crescimento contínuo da força de trabalho disponível nas sociedades latino-americanas e de outros continentes.

Em nosso entendimento, para melhor ver os sinais de reconstrução das relações, modos de produção da vida e valores necessitamos adotar, como ponto de partida, o fato de estarmos vivendo a crise mais aguda do sistema e do modo de produção capitalistas, desde as ocorridas entre 1914 e 1945, mas com todos os sentidos aguçados à procura de sinais e caminhos de saída.

Enfim, pressupomos que a crise atual precede a pandemia da Covid-19, mas, indubitavelmente, é por ela potencializada ou mesmo com ela confundida. Em verdade, à Covid-19 e aos seus efeitos vêm se somar a queda da produção industrial, comércio, serviços e até das taxas de juros (negativas), tendências que estavam em curso em quase toda economia mundial antes dessa pandemia. Além disso, há décadas, a financeirização da economia, a super-exploração da natureza e do trabalho humano, a destruição dos biomas naturais e dos seres vivos que neles habitam, o genocídio dos povos tradicionais e originários, a eliminação de conquistas e direitos sociais vêm afetando profundamente as condições de vida da imensa maioria da população do planeta. Nesse contexto, até as medidas oficiais, destinadas a mitigá-las, revelam as prioridades do sistema: salvar a hegemonia financeira pela doação de dinheiro público aos bancos e especuladores. Trata-se de salvar alguns setores e deixar o fogo da crise de acumulação do capital queimar outros.

Naturalmente, essa não pode ser a alternativa. Afinal, os números da desigualdade, pobreza e da concentração da riqueza são uma consequência do mesmo modelo de desenvolvimento predatório, cujos efeitos, cada vez mais dramáticos, têm posto em perigo a permanência da vida no planeta. Consequentemente, a pandemia de Covid-19 é uma situação que também evidencia uma profunda fratura ética e moral, especialmente entre os grupos que estão no poder. Tanto assim que, enquanto a sociedade está confinada e a economia desacelera, os ecossistemas naturais se recuperam. O panorama das grandes cidades, sem a vertigem dos carros e indústrias, com uma atmosfera mais transparente, animais selvagens a correr ao longo das praias e cidades, são claros sinais da incompatibilidade entre a natureza (a vida em sua diversidade) e o modelo vigente.

Uma questão que se pode colocar, após este período 'especial': será que vamos conseguir gerar as grandes transformações humanas (sociais, econômicas, políticas, 
ecológicas) que são imperativas para o 'bem viver' e para a economia pós-capitalista? O que se pode dizer frente a este desafio é que há transformações em curso (ou que são indicadores destas), que nos oferecem caminhos de esperança, mas não garantias. Também se pode afirmar que, na crise mundial do capital, que agrava disputas geoestratégicas, potencializa setores ultrarreacionários e esgarça valores ético-morais, seguramente, podem-se encontrar pistas para a resposta à negação da ciência, inclusive da sua vertente médico-sanitária, tão cara à sociedade burguesa em fins dos dezenove e início do século vinte. Alguns governos e líderes mundiais se notabilizaram por isso, em geral, os que reforçaram o nacionalismo populista e a intensificação da xenofobia, que esperamos, não passarão. Em seguida, avaliamos as respostas dadas à conjuntura da pandemia por alguns governos latinoamericanos, bem como por algumas iniciativas econômicas sociais solidárias vinculadas à Rede COMPARTE.

\section{A pandemia da Covid-19: reações na América Latina}

\section{Brasil e Argentina}

O Brasil vive a Pandemia de Covid-19 divido. O governo federal recusou adotar medidas mais eficazes, conforme recomendaram as autoridades sanitárias da Organização Mundial da Saúde (OMS) e, inicialmente, até do próprio Ministério da Saúde. Com palavras e atitudes, o presidente Bolsonaro sabotou publicamente a estratégia de isolamento social e outras ações essenciais, fundamentais para conter uma maior disseminação do vírus SARSCov-19. Enquanto isso, a maioria dos governadores e prefeitos seguiu as orientações da OMS, tendo que enfrentar, além dos inúmeros desafios da doença, uma disputa com o poder federal quanto à conduta que deveria adotar a população.

Frente a orientações conflitantes, e à espetacularização da irresponsabilidade presidencial, que continuadamente provoca aglomerações e contatos sem sequer usar máscara, os brasileiros viram crescer, assustadoramente, os números de contaminados e vítimas fatais da Covid-19, sem assistência médica adequada em vários estados. Assim, já em 25 de maio, o Brasil superou aos Estados Unidos (EUA) no registro diário de mortes decorrentes do novo coronavírus. Foi a primeira vez, segundo os dados oficiais, que a pandemia fez com que o Brasil tivesse mais notificações de mortes que este país (GONÇALO 
JÚNIOR, 2020), reforçando as previsões que apontam esse país, como um dos candidatos a registrar, relativamente, o maior número de vítimas fatais ao final dessa pandemia.

Está claro, todavia, que esses resultados, que podem caracterizar um genocídio, seriam evitáveis. É o que se pode concluir observando os fatos um pouco mais ao Sul do subcontinente. Em situação econômica bem mais difícil, a vizinha Argentina demonstra que a Covid-19 podia ser enfrentada com custo humano e político várias vezes menor, ainda que isso tenha pouca visibilidade na mídia brasileira. Em maio, o índice de mortes por milhão de habitantes dos dois países indicava o Brasil com 85,6 óbitos por milhão de habitantes, enquanto a sua vizinha do Sul, quase onze vezes menos: 7,93. Nos meses seguintes verificouse um relativo crescimento de mortes na Argentina. De todo modo, o número de mortos argentinos por milhão de habitantes, em setembro, era de 307. Enquanto no Brasil, essa taxa era de 670, inferior apenas à do Peru (1011) e maior que a dos EUA (614). Em 22 de setembro, embora a Argentina vivesse seu pior momento na pandemia, a letalidade da Covid-19 era de 1 morto por 3.189 habitantes (total de mortes 13.952). Para o Brasil, essa taxa era 1 morto por 1.517 habitantes (total de mortes 138.105) (THE NEW YORK TIMES, 2020).

As diferenças mais sensíveis podem estar na postura dos respectivos governos nacionais. Ao invés de produzir conflitos, o governo argentino uniu o país, ainda que com problemas e críticas ao presidente Alberto Fernández (GONZÁLEZ, 2020). Esse governo adotou rapidamente a quarentena, convidou os cientistas a participar da formulação de políticas e envolveu a população nas ações. Em que pese a grave crise financeira e o contexto de moratória técnica frente aos credores internacionais, o governo age para minorar o dano social, que se instalou após décadas de crise e de destruição neoliberal, que deixou $40 \%$ da população argentina abaixo da linha de pobreza (MARTINS, 2020). ${ }^{1}$

Enquanto no Brasil, o presidente conclamava a sociedade a manter o comércio e até as escolas em funcionamento, considerando a Covid-19 uma gripezinha, na Argentina a atitude oficial foi radicalmente distinta, o que se vê nas respostas. Além de rastrear os contatos sociais de cada doente (o que jamais foi feito no Brasil), o Ministério da Saúde argentino submeteu à quarentena, já a partir de 10/3, todos os estrangeiros que chegavam a

\footnotetext{
1 " $81,1 \%$ da população argentina consideram ótima ou boa a gestão governamental da crise sanitária provocada pela pandemia". Ver Antonio Martins. "Tudo pode ser melhor, mostra a Argentina". Outras Palavras (Estado em Disputa), acesso em 24.05.2020.
} 
seu território, procedentes da China, Coreia do Sul, União Europeia ou Estados Unidos. Nesse mesmo dia, Bolsonaro encontrava-se em Miami com D. Trump e opinava sobre o novo vírus: "muito do que tem aí é fantasia, não é tudo aquilo que a mídia propaga". Não surpreende, por conseguinte, o Brasil não ter adotado, a tempo, qualquer controle a viajantes, capazes de introduzir o vírus no país. E não o fez a partir de uma decisão política de governo.

Ainda em 13 de março, dois dias após a Organização Mundial da Saúde (OMS) chamar a doença de pandemia, quando o país não havia relatado uma única morte por Covid-19, o Ministério da Saúde brasileiro anunciou ações que, se executadas, consistiriam em um importante ataque inicial contra a disseminação e contágio pelo corona vírus: Cancelar os cruzeiros marítimos; desaconselhar autoridades locais a permitir grandes eventos; orientar aos viajantes que desembarcavam do exterior a cumprirem quarentena.

Entretanto, no dia seguinte, o Ministério foi obrigado a recuar de suas próprias orientações, após intervenção do ministro-chefe da Casa Civil, o general Walter Souza Braga Netto. "Essa correção se deu por pressão", afirmou Júlio Croda (apud EISENHAMMER; STARGARDTER, 2020) epidemiologista que, à época, chefiava o Departamento de Imunização e Doenças Transmissíveis do Ministério da Saúde. A partir dessa data, o poder mudaria do Ministério da Saúde, tradicional líder em questões sanitárias, para o gabinete desse militar, alçado à burocracia estatal. Na sequência, ocorreria o contínuo enfraquecimento do ministro da saúde e do próprio Ministério, que seguiu sem uma estratégia clara contra a pandemia.

Duas políticas, dois resultados: no dia em que Fernández decretou a quarentena radical $^{2}$, o índice de mortos por milhão na Argentina era o dobro do brasileiro. Em 20 de maio, a taxa brasileira já era dez vezes maior que a Argentina.

Em desalinho com os temores iniciais do controle social pelo Estado 3 , o controle da circulação em tempos de emergência sanitária mostrou-se essencial, sem, necessariamente, implicar em aumento do poder do Estado sobre os cidadãos. Para isso, parece essencial o

\footnotetext{
${ }^{2} \mathrm{O}$ 'isolamento social preventivo e obrigatório' permitia a cada argentino sair de casa apenas uma vez a cada dois dias (o controle é feito, par ou ímpar, segundo o algarismo final da carteira de identidade), podendo circular em um raio de, no máximo, 500 metros. A multa, em caso de descumprimento, é equivalente a $\mathrm{R} \$ 7$ mil.

3 Segundo Agamben (2020) a pandemia vem sendo usada para manter o estado de exceção "como paradigma normal de governo". A covid-19 substituiria a estratégia de guerra ao terrorismo. Os indivíduos, em nome da segurança, tenderiam a aceitar as restrições à sua liberdade. Não é o que estamos vendo, sobretudo depois dos protestos antirracistas, iniciados nos EUA, e antifascistas em vários países.
} 
envolvimento e a participação social ativa da população; este parece ter sido o caso da Argentina e também do Uruguai.

A Casa Rosada, respondendo às urgências da saúde e da economia, constituiu um comitê de sanitaristas, trabalhadores e empresários para assessorar cada passo das medidas oficiais. Também incluiu no diálogo representantes da oposição, buscando unir forças contra a pandemia. O governo, ouvindo as centrais sindicais, editou um Decreto de Necessidade e Urgência (equivalente às Medidas Provisórias no Brasil), proibindo demissões de

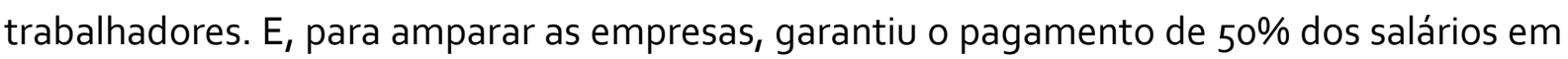
caso de relevante queda das receitas. Para as pequenas empresas e microempreendedores estabeleceu crédito especial, com taxa de juros zero.

Nesse contexto floresceu o protagonismo popular. El Barrio cuida al Barrio surgiu como movimento social para dar assistência aos infectados leves. Assim, as casas mais humildes, onde possa haver doentes, são visitadas por mobilizadores populares articulados pela União de Trabalhadores da Economia Popular (UTEP) que tem, entre suas origens, o movimento dos piqueteiros. Já o governo, entregou a gestão do Mercado Central de Buenos Aires a Marcos Levaggi, referência da União dos Trabalhadores da Terra (UTT) e um dos líderes do movimento agroecológico desse país, conhecido desde os Verdurazos. 4

Como resultados dessas políticas, a Argentina colheu uma adesão ao distanciamento social superior aos $75 \%$, que resulta na menor letalidade da pandemia. $E$, desde 11 de maio, a quarentena começou a ser amenizada - exceto na região em Buenos Aires, que concentra cerca de 80 \% dos casos do país. Seguramente, os prejuízos econômicos serão bem menos traumáticos, embora, ao mesmo tempo, tenha tido que lidar com os credores dos fundos abutres, que controlam grande parte da enorme dívida externa nacional (MARTINS, 2020) ${ }^{5}$.

\footnotetext{
4 Cultivadores de hortas rurais na periferia de Buenos Aires que desafiavam a polícia, ocupavam as praças principais da Capital e outras cidades e vendiam seus produtos diretamente à população.

${ }^{5} \mathrm{~A}$ dívida argentina apenas com os credores privados - em sua maioria fundos abutres (como Black Rock, Franklin Templeton e o PIMCO) -, chega U\$ 66 bi, pagando-lhes juros de $7 \%$ ao ano, enquanto as taxas mundiais, hoje, giram em torno de $0 \%$. O poder desses atores centrais do capital financeiro especulativo pode ser dimensionado pelo Black Rock, surgido em 1988. Este fundo reúne sozinho investimentos de 3 trilhões de dólares - o dobro do PIB do Brasil e, como os demais, não são regulados por Estados ou Bancos Centrais. Como não operam junto ao público, não possuem reputações a zelar, muito menos estão sujeitos a pressão social (MARTINS, 2020). Multiplicam seus capitais, especulando com papéis e títulos, sugando os orçamentos públicos no planeta, e são a marca do capital na era neoliberal.
} 
O caminho seguido pelo Brasil pode ser resumido como o inverso do percorrido pela Argentina. Bolsonaro provoca conflitos com os governadores dos estados, com ministros do Supremo Tribunal Federal, com a imprensa e até com os seus próprios pares. De sua lista de desafetos não escapa também a China, de onde proveio (2019) um superávit de US\$27,6 bilhões do comércio exterior e é o destino de cerca de $40 \%$ das exportações do país (PRINCIPAIS..., 2020) $)^{6}$.

Em meio ao avanço da crise sanitária, o governo brasileiro agudizou a crise politica. $\mathrm{O}$ país vive em ambiente de tensão quase permanente. Nesse contexto, cresceu a consciência política quanto à natureza fascista do projeto em curso, sobretudo, após a divulgação do conteúdo de uma reunião ministerial, onde ameaças de todo tipo foram feitas, de prisão para ministros da Corte Suprema e governadores até o armamento da população para fins políticos. Isso se somou à participação presidencial direta em manifestações de rua, patrocinadas por grupos e empresários de extrema direita, que pedem o fechamento do Legislativo, da Suprema Corte e o retorno da Ditadura Militar. Em uma dessas, lembrando Luís XIV, afirmou: "a Constituição sou eu". Assim, interferiu pessoalmente em instituições de Estado, como a Polícia Federal, para defender filhos e aliados, investigados 'injustamente' por crimes de apropriação de parte dos salários de servidores empregados em seus gabinetes no Poder Legislativo (caso das 'Rachadinhas'). Se todos esses conflitos lhes causam problemas com autoridades, também mobiliza sua base social mais conservadora.

Por outro lado, os efeitos sociais positivos do 'auxílio emergencial' distribuído para mais de 60 milhões de brasileiros têm the possibilitado melhorar a popularidade. Efetivamente, o "auxílio" de 600 reais, entre abril e agosto, apesar de inúmeros problemas, chegou a injetar 50 bilhões de reais ao mês. Será mantido a partir de setembro, até dezembro, mas com a metade do valor e com critérios mais restritivos de concessão (BOLSONARO, 2020). O efeito principal desses recursos foi dinamizar a economia dos setores populares (alimentos, construção civil...) e produziu uma efetiva melhora na avaliação popular do governo (ALMEIDA, 2020)7. E não por acaso, afinal os gastos de apenas um mês do 'auxílio'

\footnotetext{
${ }^{6}$ No caso da China, unicamente, para seguir a política externa estadunidense, ainda que em desacordo com os interesses econômicos do país e com a tradição diplomática brasileira, marcada pela independência e não alinhamento automático com os EUA (PRINCIPAIS..., 2020).

7 Entre os desempregados, em julho, a reprovação caiu nove pontos em relação a junho, de 43\% para 34\%. Já o apoio subiu 12 pontos, de $24 \%$ para $36 \%$, no mesmo período. (ALMEIDA, 2020).
} 
correspondem a um aumento de $47 \%$ em relação aos quase $\mathrm{R} \$ 34$ bilhões que o governo desembolsou em todo o ano passado com o programa Bolsa Família.

Para Rogério Barbosa, sociólogo do Centro de Estudos da Metrópole da Universidade de São Paulo (USP), o 'auxílio' foi responsável por uma queda (da desigualdade) sem precedentes. E que, "se não houvesse o 'Auxílio', o esforço redistributivo dos últimos 25 anos teria se perdido" durante a pandemia (ALMEIDA, 2020).

Gráfico 1 - Os efeitos na distribuição

\section{Os efeitos na distribuição}

O movimento do índice de desigualdade
Sem o auxilio emergencial, indice subiria para 0,569 , taxa semelhante à dos anos 1970 , de 0,565

Maior desigualdade

Índice de Gini, quanto mais perto de 1 , mais concentrada é a renda no país

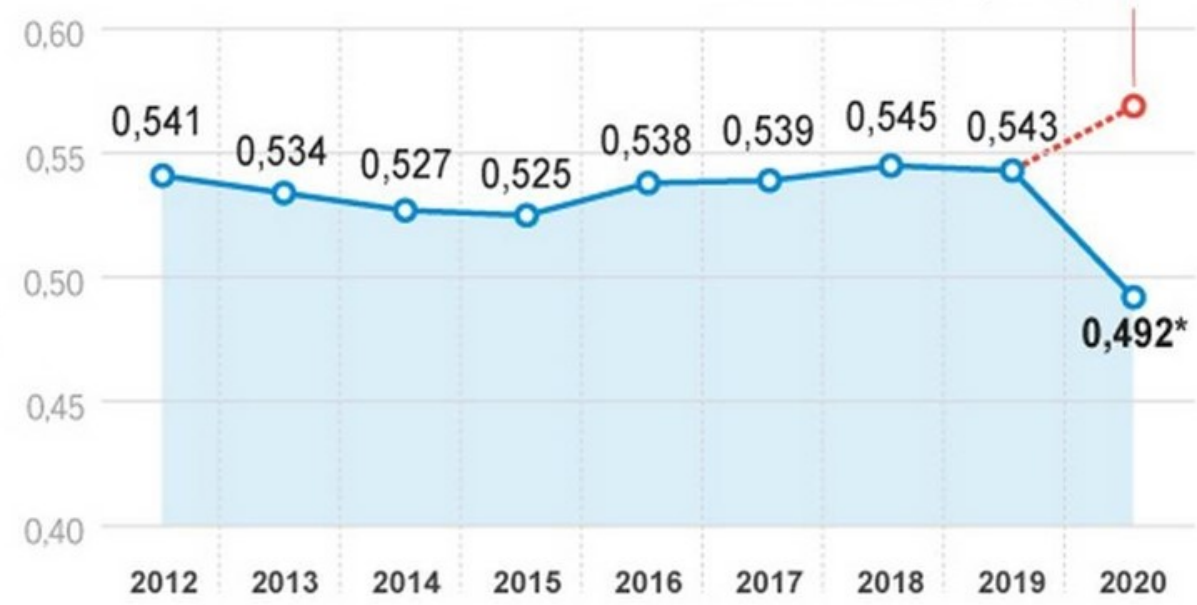

*Até maio, com base na Pnad Covid-19, do IBGE

Fonte: Estudo do sociólogo Rogério Barbosa, do Centro de Estudos de Metrópole da USP, com base nas Pnads do IBGE

Fonte: O Globo.

Em termos regionais, pelo exemplo da Bahia, onde 60\% da população recebe 'auxílio emergencial', observa-se que o auxílio representou um aumento no rendimento domiciliar per capita médio dos baianos de $25,9 \%$ (BAHIA..., 2020) ${ }^{8}$.

A popularidade obtida por meio do 'auxílio', porém, é efêmera. E o governo sabe disso, bem como das ameaças que pesam contra si. Nessa perspectiva, a prisão de colaboradores diretos dos Bolsonaros em ações ilegais (Fabrício Queiroz e esposa), a

\footnotetext{
${ }^{8}$ Quase 70\% de todos os recursos foram destinados à metade dos domicílios com os rendimentos mais baixos em termos per capita, aqueles de até R\$374,9 por mês.
} 
abertura de Inquérito Policial para apurar ameaças de membros do governo aos ministros da Corte Suprema, dentre outros fatores, levaram à desmobilização das manifestações fascistas pró-golpe. ${ }^{9} \mathrm{O}$ governo, então, passou a investir em alianças com os setores políticos mais conservadores, parlamentares do chamado 'Centrão' (grupo fisiologista caracterizado pela troca de cargos e verbas por apoio parlamentar), a acenar com investimentos públicos, ampliação do Bolsa Família e a propagandear ter feito grandes esforços contra a Covid-19.

Assim, apesar de Bolsonaro ter efetivamente trabalhado a favor do SARS-Cov-19, seu governo de extrema-direita parece ter adquirido certa estabilização / aceitação das elites e grupos de poder, a partir do terceiro quadrimestre de 2020, ao mesmo tempo em que parece ter se tornado refém do 'auxílio', que tem data final para deixar de existir.

Talvez, por isso mesmo, não retroceda um milímetro na ameaça autoritária e antidemocrática. Assim, o governo não descuida de sua base de sustentação real, o poder militar. Nessa direção, atrai cada vez mais militares para cargos civis no governo. Já são 11 generais no ministério e, conforme o TCU (Tribunal de Contas da União), são 6.157 militares ocupando cargos civis, em comparação com 2.765, em 2018. Eles estão em conselhos de empresas estatais, na alta administração do Poder Executivo, cargos comissionados, na administração pública etc. (REZENDE, 2020).

Por esse caminho, a militarização da gestão governamental alcançou o próprio Ministério da Saúde. Depois da saída de dois ministros, médicos e civis, ocupou o cargo mais um general do Exército, efetivado em meados de setembro, quatro meses após permanecer interinamente na função. ${ }^{10}$ Somente em cargos de profissionais da saúde são 1.249 militares. Antes do governo Bolsonaro, eram 718.

Não por acaso, o Brasil tinha, em fins de setembro, o terceiro maior número mundial de infecções (4.700.000), o segundo maior número de óbitos por Covid-19 (cerca de 150 mil mortes), contabilizando $14 \%$ das mortes, tendo apenas $3 \%$ da população mundial. Assim, o país avança para confirmar as previsões mais sombrias sobre o total de vítimas entre seus

\footnotetext{
9 As consequências dessas prisões, todavia, foram suavizadas pela inédita concessão de prisão domiciliar, por juízes das mais altas cortes, para a esposa foragida da justiça do assessor dos Bolsonaros.

${ }^{10} \mathrm{O}$ Ministro Luiz H. Mandetta foi demitido, dentre outras razões, por manter a orientação de isolamento social da população contra a opinião do presidente. Nelson Teich pediu demissão, com menos de um mês no cargo, por discordar de Bolsonaro sobre a recomendação de uso da cloroquina como forma de tratamento da Covid19.
} 
habitantes. Seguramente, boa parte desse genocídio poderia ter sido evitada com uma postura governamental condizente com as recomendações médico-científicas.

Observando o contexto latino-americano, contudo, vê-se que o Brasil não é o único caso de descontrole da pandemia, em meio à crise social que caracteriza o subcontinente.

\section{Colômbia, Peru e México}

Sem dúvida, a Colômbia e o Peru foram os primeiros países da América do Sul a tomar medidas de confinamento porque as infecções iniciais foram causadas por viajantes que entravam pelos aeroportos. Na Colômbia, a pressão dos líderes dos partidos de oposição ao atual governo exigiu unanimemente o fechamento das fronteiras, a cessação das atividades das companhias aéreas nacionais e estrangeiras, para além do início do isolamento obrigatório de toda a população.

Além disso, na capital Bogotá, com mais de 8 milhões de habitantes e governada pelo Partido Verde, que se opõe ao atual governo nacional, ocorreu, no início de março, uma simulação de isolamento preventivo durante 4 dias, com o objetivo de realizar um exercício educativo em preparação para um encerramento por tempo indeterminado. Esta iniciativa foi copiada por vários líderes locais do país. Esta situação forçou o governo nacional a decretar o isolamento preventivo obrigatório em todo o território nacional a partir de 24 de março, dia em que o exercício terminou na capital.

No Peru e no México, o Covid - 19 teve um rápido crescimento, dois países que, com o Brasil, apresentaram as estatísticas mais elevadas de progresso do Covid-19 na América Latina, seguidos pelo Chile, Equador e Colômbia.

Em outubro, a Colômbia comunicou um total de 934.000 casos confirmados e 28.141 mortes, o México 825.340 casos e 84.4320 mortes, e o Peru 853.974 casos confirmados e 33.419 mortes. No que diz respeito aos relatórios globais, classificam-se em $11^{\circ}, 4^{\circ}$ e $7^{\circ}$ lugar entre os países com maior mortalidade. Estes dados, acrescentados ao caso do Brasil, mostram a elevada incidência da doença na América Latina e nas Caraíbas, que reportaram um total de 9.876 .651 casos de Covid-19 até 9 de outubro de 2020, mais de 5 milhões dos quais no Brasil. 
Da análise da evolução da doença no mundo, foi sugerido que, mais do que uma pandemia, deveria falar-se de uma sindemia (PLITT, 2020), ${ }^{11}$ uma vez que existe SRA-CoV-2 e, por outro lado, uma série de doenças não transmissíveis. Estes dois elementos, que interagem num contexto social e ambiental caracterizado por uma profunda desigualdade social, exacerbam o impacto da doença.

É importante lembrar que, antes da pandemia, vários países no mundo, e em particular na América do Sul, estavam envolvidos em grandes mobilizações sociais devido ao impacto do Estado-providência e Estados sociais falhados. Organizações sociais, sindicatos e a população em geral estavam nas ruas exigindo trabalho decente, exigindo a proteção da vida e dizendo já muito sobre as ações predatórias dos bens da natureza.

Antes da pandemia, a economia da região já experimentava fragilidades profundas, caracterizadas por uma elevada concentração de riqueza. É neste contexto que a pandemia chega e desmantela esta cruel realidade. Neste sentido, a crise tem uma matriz original diferente e que a situação da pandemia a revelou e agravou de uma forma evidente. Portanto, restringindo o olhar única e exclusivamente aos efeitos da pandemia, limita o olhar do que vem de trás. Os números da CEPAL (INFORME...,2020) mostram que este é o caso ${ }^{12}$.

Os dados com estimativas médias de pobreza e pobreza extrema em 2020, segundo a CEPAL (INFORME...,2020), sem considerar as medidas para mitigar os efeitos da Covid-19, tinham sido projetados para o Brasil em 7,4 e 24,3, o Peru em 4,6 e 19,1, a Colômbia em 12 e 31,5, o México em 14,9 e 47,8 e a Argentina em 5,1 e 33,6 respectivamente, mostram uma América Latina empobrecida, que contrasta com os números de concentração da riqueza, um dos mais elevados do mundo.

Além disso, e devido ao impacto da crise Covid-19, a CEPAL (INFORME...,2020) estima que cerca de $10 \%$ das pessoas que se encontravam numa situação de pobreza não

\footnotetext{
${ }^{11}$ Richard Horton, editor-chefe da prestigiosa revista científica The Lancet, defende o uso desse neologismo, argumentando que na crise sanitária atual, existe além do Sars-CoV-2 uma série de doenças não transmissíveis que lhes são sinérgicas. Assim, cunhou a nova expressão para designar essa interação e seus efeitos diversos. Advoga, ainda que um quadro conceitual mais amplo abra caminho para encontrar soluções mais adequadas (PLITT, 2020).

${ }^{12}$ La pandemia del Covid-19 tiene fuertes efectos en el ámbito de la salud y profundas implicaciones sobre el crecimiento económico y el desarrollo social. Llega a América Latina y el Caribe en un contexto de bajo crecimiento y, sobre todo, de alta desigualdad y vulnerabilidad, en el que se observan tendencias crecientes en la pobreza y pobreza extrema, un debilitamiento de la cohesión social y manifestaciones de descontento popular. (INFORME...,2020).
} 
extrema em 2019 (11,8 milhões de pessoas) veriam a sua situação econômica deteriorar-se e cair numa situação de pobreza extrema. Da mesma forma, 15\% das pessoas pertencentes a camadas baixas não pobres (entre 1 e 1,8 linhas de pobreza per capita) cairiam em pobreza não extrema (20,8 milhões de pessoas) ou pobreza extrema (3 milhões de pessoas) (INFORME...,2020). Embora estes números não especifiquem a situação específica da pobreza nas zonas rurais.

Por outro lado, os números relativos ao trabalho informal na região situam-se entre 40 e 60\%, ou seja, uma grande parte da população depende da atividade quotidiana sem a garantia da segurança social, e, adicionalmente, $80 \%$ do emprego formal provém de pequenas e médias empresas, setores que foram duramente atingidos pela queda na procura de produtos durante o período de isolamento preventivo obrigatório, que em alguns países ultrapassou as 12 semanas. Em alguns casos, esta situação tem sido um terreno fértil para o crescimento de uma economia predatória e especulativa, que afeta diretamente as populações de baixo e médio rendimento.

Estas realidades marcam a matriz da desigualdade social na América Latina, que inclui não só os estratos socioeconómicos, mas também o género, a etnia e o território, entre outros. No que diz respeito ao nível territorial e populacional, a situação pode ser ainda mais crítica nas populações rurais e, em particular, nas comunidades camponesas, indígenas e negras, onde a ausência do Estado e a falta de políticas estruturais impedem o acesso a direitos fundamentais destas populações.

A concentração da riqueza, da terra e dos rendimentos é extrema na região. Em termos de rendimento per capita, a América Latina e Caribe é a região mais desigual do mundo, seguida pelos países subsaarianos. Em riqueza e bens, a desigualdade é também muito elevada, com um índice de Gini de o,809, em 2014 (COMITÊ..., 2016).

Quanto ao acesso a terra, antes e durante a pandemia, os processos de digitalização da governança da terra, recém-implantados para resolver direitos de propriedade por meio de cadastros com o georreferenciamento das áreas, vêm negligenciando a regularização dos territórios coletivos em toda América Latina. Esse processo tem criado as bases para a apropriação de terras para o mercado financeiro e fundos de investimentos. Ao mesmo tempo, observa-se a interrupção da reforma agrária e a suspensão dos processos de titulação coletiva das terras comunitárias (CUNHA, 2017). Avançam as políticas e leis específicas para atração de investimentos do mercado de capitais em terras, infraestrutura logística e nas 
cadeias de valor do agronegócio, tendo como lastro patrimonial as dívidas contraídas, desde a terra até serviços ambientais. Nesse sentido, são exemplos as Zonas de Investimento para o Desenvolvimento Rural, Econômico e Social (ZIDREs) na Colômbia e a transformação dos títulos do agronegócio, no Brasil, em ativos mobiliários geridos pelo mercado financeiro, inclusive em moeda estrangeira, e com isenção de impostos em suas transações (CERCAS..., 2020).

Na vida rural, indígena e quilombola, o isolamento não é único nem novo. Os litígios sobre controlo territorial, projetos extrativos, concentração da propriedade da terra e a ausência de políticas públicas rurais coerentes com a realidade social, cultural e econômica da ruralidade são cotidianas.

Para além dos números econômicos e dos seus impactos, no contexto do Covid-19, podemos reafirmar que, num período de semanas, o planeta tornou explícita a ameaça causada pelo modelo civilizador, cuja construção, embora tenha começado há cerca de três séculos, teve impactos profundos no planeta "afectando ciclos de materia, agua y energía, trastocado valores casi eternos, transformado visiones ancestrales, dislocado las vidas cotidianas, y creado audaces, racionales y astutos individuos... que destrozarían al mundo si ello fuera rentable" (TOLEDO, 2010).

Por esses motivos, torna-se cada vez mais necessário fortalecer as iniciativas produtivas e político-organizativas dos setores campesinos e populares, no campo e na cidade, em toda América Latina, o que, por sua vez, demanda conhecimento, integração e fomento das ações e experiências desses atores. Pela mesma razão, não se deve descuidar dos aspectos relativos à sustentabilidade das iniciativas econômicas sociais e solidárias, numa perspectiva que incorpore, além da capacidade de os trabalhadores dominarem a gestão dos seus empreendimentos, o desenvolvimento de um ambiente social, político e institucional que favoreça o florescimento dessas iniciativas (KRAYCHETE, 2015). Nessa direção, a Rede COMPARTE segue buscando desenvolver a capacidade dos trabalhadores em forjar uma perspectiva econômica alternativa, bem como favorecendo a formação de lideranças, a articulação e troca de experiências em diferentes países. 


\section{A abordagem de trabalho da Rede Comparte}

A Rede COMPARTE, vinculada à CPAL (Conferência dos Provinciais da Companhia de Jesus na América Latina), está presente num universo rico e variado de iniciativas e projetos, tais como iniciativas produtivas locais, incubadoras de pequenos empreendimentos, empresas sociais, fundos de financiamento solidários, programas mistos de políticas públicas, dentre outros. A Rede está presente em comunidades populares, indígenas, negras (quilombolas) e camponesas; também em diversas regiões como o altiplano andino, nas serras e no litoral. Atuando em tão grande diversidade, depara-se com diversos desafios e questões comuns, em situações geralmente paradoxais: comunidades carentes de bemestar, mas presentes em territórios de abundância, que, progressivamente, veem seus recursos esgotados, empobrecendo ainda mais as pessoas (AGUILAR; IDÁRRAGA, 2017).

Face à situação social, política, ambiental e econômica adversa que se vive numa grande parte da América Latina, a construção de uma base epistemológica para gerar 'alternativas ao desenvolvimento', baseada nas potencialidades e nos desafios da grande diversidade territorial que caracteriza os povos do Sul, adquire maior relevância. Devido à dureza da realidade (pobreza extrema, deterioração dos bens naturais, ausência do Estado, etc.), para a Rede COMPARTE (AGUILAR; IDÁRRAGA, 2017), o desafio vai além da reflexão teórica, e por isso tenta vislumbrar, de forma pragmática, horizontes de ação que guiam as comunidades a gerar condições de boa vida em cenários, muitos deles, hostis.

Acompanhar os empobrecidos implica melhorar os estudos, análises e reflexão, a fim de compreender em profundidade os processos econômicos, políticos e sociais que geram tanta injustiça, e contribuir para a geração de modelos alternativos.

Neste desafio, para a Rede COMPARTE, gerar alternativas ao desenvolvimento significa: (1) defender a vida, (2) construir visões e alternativas a partir do nível local, (3) gerar maiores capacidades de participação e tomada de decisões, (4) apostar na construção coletiva, (5) resgatar a riqueza da agro-biodiversidade, (6) utilizar os bens da natureza de forma justa e sustentável, (7) reforçar o papel das mulheres, e (8) conquistar a vida boa para todas as pessoas. Estas características identificam elementos essenciais da alternativa, com o objetivo de contribuir para uma transformação social que desmantele as estruturas estabelecidas de exploração socioambiental, entendendo que não existe apenas um modelo 
alternativo de desenvolvimento, mas várias e diversas lógicas que são complementares. (ALBOAN, 2011)

A Rede COMPARTE e os centros sociais a ela associados, no conjunto de ações que acompanham e gerem com as organizações de produtores, concentram suas iniciativas na dinamização de alternativas econômicas que garantam a autonomia, a possibilidade de replicação e ganhos de escala do empreendimento. Neste sentido, as Leituras Estratégicas do Território (LET) permitem uma análise exaustiva do seu potencial e dos desafios para gerar condições para uma vida boa aos seus beneficiários. Do ponto de vista econômico, a prioridade são os sistemas de produção social e culturalmente reconhecidos, e que têm um maior potencial de geração de resultados. Assim, várias cadeias de valor foram identificadas e estão sendo dinamizadas em diferentes territórios dos 11 países onde a Rede está presente, como se vê no quadro a seguir.

Quadro 1-Cadeias de valor

\begin{tabular}{|l|l|l|}
\hline \multicolumn{1}{|c|}{ País } & \multicolumn{1}{|c|}{ Região } & \multicolumn{1}{c|}{ Cadeias de valor } \\
\hline Paraguai & San Ignacio Guazú & Produção agroecológica \\
\hline Bolívia & Amazônia & Cacau orgânico \\
\hline Peru & Piura & Cacau orgânico \\
\hline Peru & Cusco & Cuyes, lacticínios, turismo rural \\
\hline Brasil & Sul da Bahia & Cacau orgânico (agroecológico) \\
\hline Equador & $\begin{array}{l}\text { Zona periurbana marginal de } \\
\text { Guayaquil. }\end{array}$ & Manufaturas \\
\hline Colômbia & Nariño, Valle del Cauca y Chocó. & $\begin{array}{l}\text { Café de alta qualidade, } \\
\text { empreendedorismo social }\end{array}$ \\
\hline Nicarágua & Villa del Carmen & $\begin{array}{l}\text { Produção e cooperativas } \\
\text { pecuárias }\end{array}$ \\
\hline El Salvador & Guaimango & Avicultura e produção de milho \\
\hline Guatemala & Quetzaltenango & Produção agroecológica \\
\hline Cuba & Santiago de Cuba & Trabalhadores autônomos \\
\hline México & Chiapas & $\begin{array}{l}\text { Café orgânico, mel orgânico e } \\
\text { sabão artesanal }\end{array}$ \\
\hline
\end{tabular}

Fonte: elaborado pelos autores

Com base no enfoque do desenvolvimento humano local, a Rede procura fomentar o potencial de cada região representada nos sistemas de produção, iniciativas produtivas e/ou empresas sociais para aumentar as atividades econômicas alternativas, conectar local e 
globalmente as múltiplas partes interessadas, e promover modelos complexos de colaboração (economia social, instituições de fomento, movimentos sociais etc.).

\section{Iniciativas e aprendizados na conjuntura da pandemia}

Brasil

No Brasil, o Centro de Estudos e Ação Social (CEAS) atualmente é o único associado à Rede COMPARTE. Seu trabalho com comunidades populares está situado nas regiões sul e sudoeste do Estado da Bahia (com agricultores familiares e sem terras), e na capital do Estado, Salvador, com movimentos por moradia e de sem tetos.

A realidade socioeconômica de atuação do CEAS se caracteriza pela pobreza, inclusive em sua versão extrema, sobretudo em Salvador, onde vivem mais de 3 milhões de habitantes. O perfil de rendimentos dessa população apresenta 70\% com renda igual ou inferior a dois salários mínimos, um alto grau de informalidade e concentração das atividades no setor de serviços e do pequeno comércio (CARVALHO; PEREIRA, 2015), além de uma taxa de desemprego aberto em torno de $18 \%$, mesmo antes da pandemia. No contexto atual da Covid-19, que levou ao fechamento do comércio considerado não essencial, mas também do comércio informal ou de rua, essencial para as famílias que dele vivem, as condições de sobrevida da maioria da população da capital tornaram-se ainda mais dramáticas. Essa população, em geral, reside em zonas da cidade muito precárias e assemelhadas às 'favelas' ou 'comunidades'.

Os impactos causados pela pandemia sobre a população favelada são inquestionavelmente mais sérios. No caso do Brasil, esse contingente de pessoas chega a 13,5 milhões concentradas nas grandes cidades brasileiras. A maior vulnerabilidade das favelas ao coronavírus deve-se à combinação da falta de espaço, escassez de recursos, poupança, estoque de comida e saneamento básico. Nesses locais, para onde o racismo estrutural enviou principalmente a população negra, $15 \%$ das famílias não têm sabão disponível e falta água potável em $47 \%$ dessas moradias (GUIMARÃES, 2020). Não surpreende, portanto, que a alta comissária de Direitos Humanos da ONU, Michele Bachelet, tenha alertado para o impacto devastador da Covid-19 sobre grupos étnicos discriminados, principalmente em países como Brasil, França, Reino Unido e EUA. Neste último, a taxa de mortalidade de Covid- 
19 para afro-americanos é mais do que o dobro de outros grupos raciais (CENTRO DE INFORMAÇÕES DAS NAÇÕES UNIDAS NO BRASIL, 2020). Embora ainda não se conheça essa relação para o Brasil, o estudo da ONU, usando dados de São Paulo, afirma que a população negra tem $62 \%$ mais risco de morrer do que as pessoas brancas. Apesar disso, as favelas não contam com um plano nacional específico de prevenção e combate à Covid-19. Essa situação legitima a hipótese de que a pandemia possa se converter em 'mecanismo de controle populacional', ainda que não intencional (LEONÍDIO apud RACISMO..., 2020).

Esse quadro nacional pode ser visto também em Salvador, que, historicamente, apresenta índices de desemprego e informalidade superiores à média nacional, e cujo recorte demográfico-racial a caracteriza como a maior cidade negra fora do continente africano. Salvador apresenta, ainda, um contexto de crescente especulação imobiliária, que afeta o seu Centro Antigo, com tentativas continuadas de expulsão dos moradores mais pobres, rostos majoritariamente negros e femininos, contra as quais lutam movimentos sociais apoiados pelo CEAS.

Agindo contra a gentrificação do Centro antigo, pretendida por representantes do capital turístico e setores do Estado, encontra-se também o Movimento dos Trabalhadores Sem Teto da Bahia (MTST), outro importante aliado do Centro de Estudos e Ação Social. Nesta parceria, além das ações de resistência no Centro, são realizados contínuos processos de luta pela conquista do direito à moradia digna na periferia da capital, em ocupações organizadas pelo movimento social. Nessas áreas, as condições de moradia e habitabilidade são extremamente precárias, o que dificulta enormemente o combate à Covid-19.

A atuação urbana do CEAS também dialoga com aquilo que os movimentos parceiros consideram ser a construção do 'bem viver' nos territórios por eles conquistados, seja no centro, seja na periferia, ainda que se encontrem nas etapas iniciais desse projeto. Vale dizer, ainda lutam pela preservação desses territórios e a conquista de uma moradia digna. Ademais, em tempos de pandemia, a utopia do 'bem viver' se distancia ainda mais da realidade concreta, porém, por meio das relações de solidariedade e empatia com outros sujeitos sociais, toma formas muito mais efetivas.

Essa efetividade pode ser percebida nas ações postas em andamento pelos camponeses do sul e sudoeste da Bahia. Nessas regiões, homens e mulheres realizaram uma intensa mobilização dos fatores produtivos com que contavam em seus territórios, inclusive muitos jovens entre eles/as; ou que, na ausência de meios, puderam mobilizá-los com o apoio 
do CEAS. Dessa mobilização coletiva resultou a produção, para distribuir nas comunidades carentes locais e de Salvador, de aproximadamente dois mil litros de álcool antisséptico - 70 graus, 4 toneladas de alimentos e de mais de mil máscaras anti-contágio. Os atores da economia social e solidária mostraram, além de empatia com os necessitados, um claro compromisso sociopolítico em defesa da vida, nem sempre presenciado entre setores da própria elite governante brasileira.

Assim, em meio aos problemas e restrições impostas pela pandemia, pôde-se perceber os sinais do estreitamento dos laços de solidariedade entre coletivos sociais urbanos e rurais. E, partir destes, vislumbram-se novos vínculos entre campo e cidade. Novos caminhos de integração, que, certamente, terão na produção e circulação de alimentos saudáveis (orgânicos ou agroecológicos) uma ampla rota para seguir. E por meio dela, a formulação de alianças sociopolíticas mais profundas, tendo em vista, quem sabe, a utopia do 'bem viver' nesses dois mundos, até então conectados, basicamente por laços mercadológicos.

No campo, as dificuldades são diferentes, mas igualmente desafiadoras, quando se pensa em enfrentar a pandemia. Produzir e distribuir alimentos, bem como meios de prevenção contra a Covid-19, sem se aprisionar nas malhas do circuito e das relações mercantis tradicionais, além de se protegerem, foram objetivos que as organizações produtivas apoiadas pelo CEAS se colocaram no atual contexto, ensaiando construir uma economia social e solidária.

Isso não tem sido fácil em todo subcontinente. No Brasil do nono maior Produto Interno Bruto (PIB) e também do décimo maior índice de desigualdade social do mundo, escapar das amarras mercantis para construir uma economia alternativa e solidária torna-se

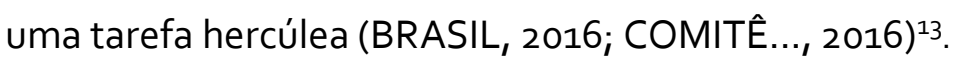

Até por isso, não se pode dizer que toda a cadeia de suprimentos necessária à produção dos itens antes mencionados tenha sido suprida por setores não mercantis. Ou que

\footnotetext{
${ }_{13}$ Nesse país, 27 mil pessoas (0,1\%) dentre 27 milhões de declarantes do Imposto de Renda de Pessoa Física possuem $\mathrm{R} \$ 44,4$ bilhões em rendimentos tributáveis e os estabelecimentos rurais a partir de mil hectares (o,91\%) concentram 45\% de toda a área de produção agrícola, de todo o gado e plantio florestal (BRASIL, 2016; COMITÊ..., 2016).
} 
os agricultores, que têm custos elevados em relação as suas possibilidades, não tenham recebido apoio de organizações parceiras para realizarem a produção de alimentos e álcool ${ }^{14}$.

O elemento essencial, no entanto, é outro. São os valores, a empatia, a solidariedade, espírito de colaboração, envolvimento, o abrir mão do sossego do lar e mesmo de valores monetários maiores para seus produtos (caso dos produtores de cana, que receberam menos pelo álcool $75^{\circ}$ do que obteriam se produzissem cachaça), ou dedicar-se ao trabalho gratuito, voluntário, como o realizado pelas mulheres que confeccionaram as máscaras. Essa economia enraizada dos oprimidos não está disponível em toda a sociedade, muito menos no mercado e nas relações capitalistas de produção e consumo. Nesse momento de crise profunda do próprio capital, contudo, tais valores afloram entre os trabalhadores, indicando que outro mundo é possível, uma economia social solidária e valore ético-morais humanistas podem se elevar acima da razão mercadológica capitalista. No Brasil, movimentos sociais rurais e urbanos deram exemplo disso.

Em várias regiões do Brasil, o Movimento dos Trabalhadores Rurais Sem Terras (MST), até maio, doou 600 toneladas de alimentos, sob a forma de cestas básicas, às comunidades carentes urbanas, sem tetos e comunidades de trabalhadores estrangeiros desempregados. Ações semelhantes têm feito dezenas de organizações que integram a Frente Brasil Popular (FBP) e a Frente Povo Sem Medo (FPSM) em diversas regiões do Brasil, que organizaram, respectivamente, a 'Campanha Periferia Viva' e 'Vamos precisar de todo mundo'. No campo popular, também surgiu a frente 'Periferia Viva' atuando com a doação de alimentos associada ao processo organizativo e de discussão política nos bairros e nas periferias (MAFORT, 2020), não esquecendo outras iniciativas solidárias nascidas nas favelas, mas patrocinadas por grandes empresas, bancos e fundações privadas, como a Central Única das Favelas (CUFA).

A capacidade de apoio do campo à cidade, pela ação solidária dos movimentos sociais, todavia, foi profundamente solapada pelo desmonte levado a cabo por vários governos, e aprofundado com o golpe institucional de 2016, via a não realização da política pública de reforma agrária; por meio da redução ao fomento à agricultura familiar, com a

\footnotetext{
${ }^{14}$ Para os agricultores, contribuíram Heks-Eper e Cese com recursos, articulados pelo CEAS.
} 
drástica redução do Programa de Aquisição de Alimentos (PAA) ${ }^{15}$ e da não universalização do Programa Nacional de Alimentação Escolar (PNAE), que, por lei, deveria adquirir 30\% da merenda escolar, no mínimo, junto aos produtores camponeses ou familiares, assentados da reforma agrária, indígenas e quilombolas.

Seguramente, as organizações camponesas fariam ainda mais, caso não sofressem com dificuldades para ampliar a capacidade de produção, dada a ausência de assessoria técnica, de crédito ou mesmo pela carência de terras. ${ }^{16}$ Mesmo com a pandemia, os camponeses, com uma política mais favorável, poderiam realizar uma ampla distribuição de alimentos durante a quarentena. Infelizmente, os governos, federal e os estaduais, inclusive os da Bahia e São Paulo, além da grande maioria das prefeituras, preferiram comprar alimentos junto às grandes empresas ou implantaram cartões para a aquisição desses produtos, com certo limite de crédito, em substituição à alimentação distribuída nas escolas, fechadas nesse período. Muitos contratos com agricultores (do PNAE) foram suspensos pelos entes públicos. Os resultados são enfraquecimento do setor, substituição de alimentos saudáveis por industrializados, com redução da capacidade imunológica das crianças, quando o momento exige estimular a produção e distribuição de frutas, verduras, legumes..., comida sem veneno, agroecológica.

Nessa conjuntura, a sociedade civil, a exemplo dos associados da Rede COMPARTE, tem usado estratégias que potencializam as ações solidárias dos movimentos sociais. Para isso, a intervenção destes, por meio da metodologia multi-atores, tem sido fundamental em seus territórios.

No caso da produção de álcool $70^{\circ}$, antisséptico, pela Associação dos Produtores de Cana e Cachaça de Itarantim (APC-Ita), a parceria com a Universidade Estadual do Sudoeste da Bahia (UESB) foi fundamental. Toda orientação científica, testagem, manipulação, controle de qualidade e rastreabilidade, além de envase do produto foram realizados no Laboratório de Tecnologia de Produtos de Origem Vegetal do Departamento de Engenharia de Alimentos (Campus de Itapetinga). Essa experiência abriu perspectivas de ampliação da

\footnotetext{
${ }^{15}$ O PAA fortaleceu redes regionais de comercialização, valorizou a produção orgânica e agroecológica, além de estimular o associativismo e o cooperativismo rural.

${ }^{16}$ Os estabelecimentos com menos de 10 hectares representam $47 \%$ do total das propriedades do Brasil, mas ocupam menos de $2,3 \%$ da área rural total.
} 
parceria com este Departamento universitário, tanto para a continuidade do fornecimento de álcool da APC-Ita para outras necessidades da UESB, como para assessoria da Universidade ao aprimoramento da produção de melaço, rapadura e açúcar mascavo, também produzidos pelos agricultores associados. Com isso, caminha para se consolidar uma segunda experiência de controle do ciclo econômico completo de um produto pelos agricultores em áreas de atuação do CEAS. Depois da experiência do cacau/chocolate orgânico-agroecológico do sul da Bahia, essa oportunidade chega ao sudoeste do estado com a APC-Ita, logrando produzir praticamente todos os derivados da cana-de-açúcar (cachaça corrente e envelhecida, melado, rapadura, açúcar e agora álcool).

Como se percebe, caso houvesse uma política efetiva de apoio aos pequenos agricultores, o protagonismo socioeconômico e as ações de solidariedade destes poderiam fazer muito mais na direção de um modo alternativo de produzir e distribuir alimentos, contra-arestando os efeitos da pandemia e da carestia de alimentos imposta pelo modo de produção e a sociabilidade burguesas. Todavia, não é o que ocorre.

O que se executa amplamente é um modelo agrário e agrícola, onde só o agronegócio, sobretudo o voltado para o mercado externo, avança com derrubadas e queimadas, devastando os biomas, como agora a Amazônia e o Pantanal testemunham. A política econômica e as antirreformas ultraliberais não permitem alcançar a segurança alimentar nutricional ou promover a agricultura sustentável, ao contrário, recolocaram o país no mapa da fome. A recente inflação nos preços da cesta básica, impulsionada pela liquidação dos estoques reguladores de grãos e o aumento da exportação de alimentos, reforça essa constatação (SOPRANA, 2020) ${ }^{17}$.

Colômbia, Perú e México

Os centros afiliados à Rede COMPARTE presentes na Colômbia, Perú e México são o Instituto Mayor Campesino (IMCA), Centro de Investigación y Educación Popular (CINEP) e Suyusama, estes na Colômbia; o Centro de Investigación y Promoción del Campesinado (CIPCA), Asociación Jesús Obrero (CCAIJO), Servicio Agropecuario para la investigación y

\footnotetext{
17 Inflação em 12 meses até julho/2020: Óleo de soja, 23,51\%; Leite, 18,79\%; Arroz, 25,55; Feijão, 48,37\% (Apas/Fipe) (SOPRANA, 2020).
} 
Promoción Económica (SAIPE) no Peru e o grupo cooperativo Yomol A'tel no México. Todos com uma longa trajetória de trabalho com comunidades rurais.

Estes sete centros acompanham as comunidades camponesas, indígenas e negras em regiões com elevadas taxas de pobreza e que, historicamente, se têm dedicado à produção agrícola, orientada, em muitos casos, nas últimas décadas, por princípios de agroecologia ou sistemas de produção sustentáveis adaptados ao conhecimento tradicional, mantido mesmo após várias gerações.

O contexto atual se desenrola com políticas públicas rurais desfavoráveis às comunidades camponesas, apesar do seu papel na produção de alimentos e outros bens e serviços. Embora os efeitos da pandemia e o isolamento social tenham marcado novas dinâmicas e percepções da vida econômica da sociedade, isto é muito mais visível nas zonas urbanas desses países, não só devido ao permanente isolamento social, político, cultural e econômico das sociedades camponesas rurais, mas também porque a sua realidade se concentra, fundamentalmente, na produção de bens de uso comunitário.

A reconstrução do quadro institucional para os cuidados comunitários parece ser a resposta e a palavra de ordem da sociedade, e deve ser uma das lições aprendidas com a crise da pandemia. De fato, as respostas das organizações sociais, grupos autônomos e indivíduos têm a ver com ações de solidariedade para satisfazer a procura de alimentos e produtos básicos das famílias em condições altamente vulneráveis no contexto urbano e também rural, particularmente entre os camponeses sem terra.

Os bens essenciais devem ser vistos como direitos e os Estados devem garantir o acesso às necessidades mínimas da vida, tais como água, alimentação, saúde e moradia, entre outras. A garantia à segurança e soberania alimentar, que tem sido a exigência e ação de muitas organizações camponesas e indígenas, está agora, mais do que nunca, na agenda da defesa de políticas públicas. Isto implica uma profunda transformação da vida rural na América Latina, onde a maioria da produção diversificada de alimentos tem a sua origem em formas de produção camponesa, que é tornada invisível pelo Estado ao privilegiar políticas empresariais e transnacionais voltadas à agro-exportação.

Mesmo duramente a pandemia, a Rede COMPARTE está empenhada em gerar experiências que reforçam a autonomia comunitária baseada na produção local de alimentos e no controlo de suas cadeias de valor. Embora o contexto atual tenha afetado a distribuição de produtos, gerando novos desafios econômicos para as organizações, foram tomadas 
mediadas e ratificada uma série de alternativas que procuram contribuir para garantir a sustentabilidade dessas iniciativas.

No caso de Yomol A'tel (México) e IMCA (Colômbia), que, em conjunto com organizações indígenas e camponesas, gerem as cadeias de valor do café agroecológico, incluso com cafeterias localizadas em universidades jesuíticas, a paralisação das aulas nestas instituições e a redução das atividades econômicas levaram ao fechamento desses cafés e, portanto, a uma dramática redução dos seus rendimentos. Isso afetou a sustentabilidade das empresas sociais Capeltic e Garittea.

Esta situação tem implicado, entre outros, dois desafios. O primeiro é manter o preço de compra do café das comunidades, que, nos últimos anos, devido ao controlo autônomo da cadeia de valor desse produto, tem sido mais elevado do que o do mercado convencional. E o segundo, é como manter a estabilidade econômica das mesmas empresas sociais garantindo empregos.

Para o primeiro desafio, a comercialização direta do café não processado, mas de alta qualidade, foi realizada com empresas e instituições que partilham a visão e os princípios da economia social e solidária, viabilizando a compra da safra dos produtores. Além disso, foram ampliados os programas de acompanhamento técnico às famílias camponesas, visando melhorar a produção alimentar nas suas plantações (milpas) e hortas agroecológicas.

Para o segundo desafio, um acordo foi feito com os trabalhadores cooperados, tendo como enfoque a defesa do emprego. Por este, parte dos seus salários não pagos foi reconhecida como um empréstimo a médio prazo, até que as lojas regressem à sua dinâmica normal de funcionamento. Além disso, outros mecanismos de comercialização de café torrado têm sido promovidos através de vendas institucionais e vendas por meio digital.

No caso da cadeia de valor do cacau, gerida pela Cooperativa de Produtores e Transformadores de Cacau de Piura (APPROCAP) e acompanhada pela CIPCA no Peru, o isolamento, devido à elevada prevalência de casos de COVID-19 na região, teve um impacto na redução das atividades na fábrica de transformação e no transporte interno do cacau. Contudo, os compromissos de exportação de cacau de alta qualidade têm sido mantidos com empresas com as quais se conseguiu uma relação de confiança e comunicação permanente.

Por outro lado, a cooperativa tem construído um maior sentido de pertença e acompanhamento com as famílias camponesas, também lhes fornecendo produtos para a 
proteção pessoal contra a infeção por Covid-19, informação sobre cuidados e prevenção, e distribuindo cestas alimentares às comunidades onde a situação se tornou mais crítica.

No caso da região de Cusco e das comunidades que CCAIJO apoia, as cadeias de valor dos produtos lácteos, cogumelos, coelhos da índia (cuyes), entre outros, embora com a comercialização afetada, possuem grande aceitação no mercado local, o que lhes tem permitido manter uma certa estabilidade na comercialização. As vendas diretas nas lojas e a abertura de vendas on-line têm sido, também, uma alternativa para o fornecimento de produtos transformados, tais como queijo curado, cogumelos da floresta e cuyes processados.

Além disso, nestas regiões foram desenvolvidas ações humanitárias para fornecer alimentos, produtos básicos e insumos de saúde, especialmente às comunidades em condições altamente vulneráveis, especialmente às pessoas que não tenham qualquer apoio do Estado ou de outras instituições. Essas ações foram realizadas pelo Servicio Agropecuario para la Investigación y Promoción Económica (SAIPE), em Santa Maria de Nieva, na Amazônia peruana, Província de grande população indígena. Neste difícil contexto, o SAIPE tem apoiado a entrega de cestas básicas e a divulgação de informação radiofónica sobre a prevenção do Covid-19 entre as comunidades.

Dessas ações sobressaem algumas importantes lições, dentre elas que a crise sanitária da Covid-19 traz à luz a crise econômica anterior, daí porque é cada vez mais importante ampliar a resiliência da produção local e criar alternativas de intercâmbio, reafirmando a opção pela soberania alimentar a partir da agroecologia. Por fim, está evidente que a nova situação de pobreza e exclusão criada pela pandemia põe à prova a capacidade de resposta do Comparte e de todos os atores da economia social e solidária.

\section{Conclusões provisórias}

A pandemia da Covid-19 realçou, ainda mais, os elevados níveis de desigualdade na América Latina e a desconexão entre os governos e a sociedade. As medidas de confinamento e isolamento social como medidas preventivas contra o avanço da doença testaram os níveis de resistência da economia do Estado em geral, das empresas e das famílias em particular, incluso os agentes da economia social e solidária. Seus profundos 
impactos econômicos e sociais afetam, em maior medida, os setores mais vulneráveis da região, num contexto de adoecimento muito amplo e cuja fase final ainda é incerta.

Registra-se o crescimento considerável do desemprego e, com isso, das condições de pobreza e da pobreza extrema, em meio a opções governamentais irresponsáveis. Ademais, a volta gradual às atividades tende a elevar o nível de informalidade na economia. Em face dessa situação, os governos não responderam ao clamor de proporcionar um rendimento mínimo vital permanente e acesso a serviços básicos, tendo, em vez disso, ampliado os subsídios e a proteção dos grandes conglomerados econômicos e especialmente do sistema bancário.

Da sociedade, foram dadas respostas que são inatas e que ressurgem em tempos de crise. Na ausência do Estado ou de suas ações pró-mercado, a solidariedade e os cuidados comunitários têm sido fontes de sobrevivência para grande parte da população, com doações de alimentos, medidas de proteção e trocas entre movimentos e iniciativas rurais e urbanas. Face às dificuldades de acesso aos alimentos básicos, foram geradas redes de colaboração que indicam claramente a urgência de construir ou ampliar circuitos curtos de comercialização e consumo, que venham a substituir o regime alimentar baseado no agronegócio. Assim, será possível ampliar o livre acesso da população a alimentos saudáveis. É imperativo fortalecer a produção alimentar nas mãos de camponeses e agricultores periurbanos para assegurar o abastecimento local de produtos frescos e a preços justos, independentemente das cadeias de mercado capitalistas. A chave para isto é a ampliação dos vínculos entre os atores da economia social e solidária do campo e da cidade, bem como a promoção de dietas saudáveis, diversificadas e sustentáveis que conduzam à redução da desnutrição e ofereçam múltiplos benefícios para a saúde humana e ao ecossistema.

Baseado na experiência da Rede COMPARTE, e tendo em vista a importância dos mercados locais, comunitários ou circuitos curtos de comercialização, é urgente criar condições político-organizativas e institucionais, em vários âmbitos, para desenvolver alternativas de economia social e solidária ou de economia popular. A função central da economia precisa ser recolocada no cuidado das pessoas, do território e da sociedade em geral. Neste sentido, existem múltiplas expressões de economias alternativas, em vários níveis de progresso e crescimento, que precisam convergir para um grande movimento social que transforme, mas, sobretudo, multiplique o princípio do cuidado com a vida. 
Naturalmente, nesse ponto, não estamos mais falando da economia capitalista, muito menos de sua etapa especulativo-financeira.

Assim, a problemática inicial posta quanto ao futuro das organizações do campo social e solidário, tomando o contexto da crise sanitária e estrutural com a qual se bate o capital, questionava a capacidade dessas iniciativas se apresentarem como guia para a reconstrução das relações sociais há tempos solapadas pela anomia ético-moral da sociedade de consumo. Nessa direção, importava perquirir suas possibilidades de gerar transformações sociais, econômicas, políticas, ecológicas na direção do 'bem viver' e de uma economia póscapitalista.

Após avaliar as experiências de alguns representantes da Rede COMPARTE e da economia solidária durante a pandemia, pode-se afirmar estar em curso um modo alternativo de produzir alimentos e iniciativas de autogestão nesses territórios dos países enfocados, que funcionam como balizas para algumas respostas provisórias à problemática inicial que, por hora, podem ser apenas esboçadas.

Com efeito, essa conjuntura ratifica o compromisso da Rede COMPARTE e das iniciativas a ela vinculadas com a prevalência dos cuidados com a vida, em toda a sua dimensão. Nessa perspectiva, o próprio contexto apelou a um maior aprofundamento do propósito de contribuir para a construção de uma economia alternativa, humana e em harmonia com a natureza, tal como tem sido promovida por várias iniciativas do campo solidário. Esta crise é um apelo urgente, dentre outros aspectos, para promover, com maior força, formas cooperativas de produção, transformação e consumo baseadas na solidariedade e na comunalidade. $\mathrm{E}$ isso foi visto nas experiências avaliadas. Mas, talvez, essa nova dinâmica ainda não tenha sido compreendida em toda a sua complexidade antissistêmica. De qualquer sorte, quem questiona, agora, que a alimentação seja mais importante do que o petróleo ou o ouro? Ou que a saúde, a água, a educação não são direitos fundamentais?

Por fim, pode-se afirmar que as experiências avaliadas se configuram como muito esperançadoras de um futuro solidário e de relações de produção harmônicas com a natureza. Efetivamente suas características apontam para uma perspectiva que está em clara oposição à economia capitalista. Mas, de antemão, não se pode afirmar que ultrapassarão o horizonte mercantil, nem que a este ficarão adstritas. Certamente, seu desfecho futuro 
dependerá de muitas variáveis, especialmente do tipo de desenvolvimento que vier a ocorrer no ambiente social, político e institucional dessas iniciativas.

\section{Referências}

AGAMBEN, Giorgio. O estado de exceção provocado por uma emergência imotivada.

Revista IHU, São Leopoldo, 27 fev. 2020. Disponível em: http://www.ihu.unisinos.br/78noticias/596584-o-estado-de-excecao-provocado-por-uma-emergencia-imotivada. Acesso em: 26 mar. 2020.

AGUILAR, J. A. P.; IDÁRRAGA, Q. A. Ruta metodológica para la construcción de alternativas económico-productivas. Lisboa: Programa COMPARTE, 2017. Disponível em: http://desarrollo-alternativo.org/wp-content/uploads/2018/04/MetodologiaDT.pdf. Acesso em: 09 dez. 2020.

ALBOAN. El desarrollo alternativo por el que trabajamos: aprendizajes desde la experiencia. Bilbao: ALBOAN, 2011. Experiencias 6. Disponível em: http://www.desarrolloalternativo.org/documentos/trabajamos.pdf. Acesso em: 09 dez. 2020.

ALMEIDA, Cássia. Auxílio emergencial reduz pobreza e desigualdade cai a menor patamar da história, mas custo é insustentável. O Globo, Rio de Janeiro, 16 ago. 2020. Disponível em: https://oglobo.globo.com/economia/auxilio-emergencial-reduz-pobreza-desigualdadecai-menor-patamar-da-historia-mas-custo-insustentavel-24589106. Acesso em: og dez. 2020.

BAHIA é o segundo estado onde mais pessoas receberam auxílio emergencial do Governo Federal, aponta pesquisa do IBGE. G1, Rio de Janeiro, 30 jun. 2020. Disponível em: https://g1.globo.com/ba/bahia/noticia/2020/06/30/bahia-e-o-segundo-estado-onde-mais-pessoasreceberam-auxilio-emergencial-do-governo-federal-aponta-pesquisa-do-ibge.ghtml. Acesso em: og dez. 2020.

BOLSONARO diz que auxílio emergencial não será prorrogado no final do ano. Gazetaweb, [Rio de Janeiro], 10 set. 2020. Disponível em: https://gazetaweb.globo.com/portal/noticia/ 2020/og/bolsonaro-diz-que-auxilio-emergencial-nao-sera-prorrogado-no-final-doano_114559.php. Acesso em: $10 \mathrm{dez} .2020$.

BRASIL. Ministério da Fazenda. Relatório da Distribuição Pessoal da Renda e da Riqueza da População Brasileira: dados do IRRF 2015/2014. Brasília, DF: Secretária de Política Econômica, 2016. Disponível em: https://www.gov.br/fazenda/pt-br/centrais-deconteudos/publicacoes/transparencia-fiscal/distribuicao-renda-eriqueza/copy_of_relatorio-distribuicao-da-renda-2016-05o9.pdf/@@download/file/relatorio-distribuicao-da-renda-2016-05-09.pdf. Acesso em: 09 dez. 2020.

CARVALHO, Inaiá Maria M.; PEREIRA, Gilberto C. P. Segregação socioespacial e desigualdades em Salvador. Cadernos do CEAS, Salvador, n. 235, p. 2-22, 2015. Disponível 
em: https://cadernosdoceas.ucsal.br/index.php/cadernosdoceas/article/view/22/19. Acesso em: 10 dez. 2020.

CENTRO DE INFORMAÇÕES DAS NAÇÕES UNIDAS NO BRASIL. ONU alerta para impacto desproporcional da covid-19 sobre minorias raciais e étnicas. Rio de Janeiro: UNIC, 2020. Disponível em: https://unicrio.org.br/onu-alerta-para-impactodesproporcional-da-covid-19-sobre-minorias-raciais-e-etnicas/. Acesso em: og dez. 2020.

CERCAS digitais: cercamento financeiro das terras agrícolas na América do Sul. GRAIN, Barcelona, 22 sept. 2020. Disponível em: https://grain.org/es/article/6531-cercas-digitaiscercamento-financeiro-das-terras-agricolas-na-america-do-sul\#sdfootnote45anc. Acesso em: 09 dez. 2020.

COMITÊ DE OXFORD PARA O ALÍVIO DA FOME. Terrenos da desigualdade: terra, agricultura e desigualdades no Brasil rural. São Paulo: OXFAM, 2016. Disponível em: https://www.oxfam.org.br/publicacao/terrenos-da-desigualdade-terra-agricultura-edesigualdade-no-brasil-rural/. Acesso em: 09 dez. 2020.

CUNHA, J. de S. Governo Temer: relações do agronegócio com o capital especulativo financeiro. Cadernos do CEAS, Salvador, n. 241, p. 301-326, 2017. Disponível em: https://cadernosdoceas.ucsal.br/index.php/cadernosdoceas/article/download/373/310. Acesso em: 10 dez. 2020.

EISENHAMMER, Stephen; STARGARDTER, Gabriel. Bolsonaro colocou generais para combater coronavírus, e Brasil está perdendo a batalha. Uol Economia, São Paulo, 04 jun. 2020. Disponível em: https://economia.vol.com.br/noticias/reuters/2020/05/26/especialbolsonaro-colocou-generais-para-combater-coronavirus-e-brasil-esta-perdendo-abatalha.htm?cmpid. Acesso em: $10 \mathrm{dez} .2020$.

GUIMARÃES, Ligia. Coronavírus: 92\%das mães nas favelas dizem que faltará comida após um mês de isolamento, aponta pesquisa. BBC News Brasil, [S. L.], 02 abr. 2020. Disponível em: https://www.bbc.com/portuguese/brasil-52131989. Acesso em: og dez. 2020.

GONÇALO JÚNIOR. Brasil já passou os Estados Unidos em número de mortes diárias. UOL, São Paulo, 26 abr. 2020. Disponível em: https://noticias.uol.com.br/saude/ultimasnoticias/estado/2020/05/26/brasil-ja-passa-os-estados-unidos-em-numero-de-mortesdiarias.htm?cmpid. Acesso em: 14 dez. 2020.

GONZÁLEZ, Enrich. Apesar de popularidade na pandemia, Fernández mantém incógnitas sobre rumos da Argentina. El País, Buenos Aires, 25 maio 2020. Disponível em: https://brasil.elpais.com/internacional/2020-05-25/apesar-de-popularidade-na-pandemiafernandez-mantem-incognitas-sobre-rumos-da-argentina.html. Acesso em: 14 dez. 2020.

INFORME especial COVID-19. Santiago: CEPAL, n. 3, mayo 2020. Disponível em: https://repositorio.cepal.org/bitstream/handle/11362/45527/5/S2000325_es.pdf. Acesso em: $10 \mathrm{dez} .2020$. 
KRAYCHETE, Gabriel. Escala e sustentabilidade dos empreendimentos econômicos solidários: uma ambiência necessária. Cadernos do CEAS, Salvador, n. 235, p. 186-206, 2015 .

MAFORT, Kelli - MST. Para combater a "pandemia da fome", MST já doou mais de 600 toneladas de alimentos. Brasil de Fato, São Paulo, 11 maio 2020. Disponível em: https://www.brasildefato.com.br/2020/05/11/para-combater-a-pandemia-da-fome-mst-jadoou-mais-de-6oo-toneladas-de-alimentos. Acesso em: og dez. 2020.

MARTINS, Antonio. Tudo pode ser melhor, mostra a Argentina. Outras Palavras, São Paulo, 20 maio 2020. Disponível em: https://outraspalavras.net/estadoemdisputa/tudopode-ser-melhor-mostra-a-argentina/. Acesso em: 14 dez. 2020.

PLITT, Laura. 'COVID-19 não é pandemia, mas sindemia': o que essa perspectiva científica muda no tratamento. BBC News Brasil, [S. L.], 10 out. 2020. Disponível em: https://www.bbc.com/portuguese/internacional-54493785. Acesso em: o9 dez. 2020.

PRINCIPAIS produtos exportados do Brasil para China. Fazcomex, São Leopoldo, 26 jun. 2020. Disponível em: https://www.fazcomex.com.br/blog/principais-produtos-exportados-do-brasilpara-china/. Acesso em: 14 dez. 2020.

RACISMO e pandemia: ' São Paulo vive o maior apartheid social do país', alerta historiador. Sputnik, Rio de Janeiro, 04 jun. 2020. Disponível em: https://br.sputniknews.com/opiniao/ 2020060415657165-racismo-e-pandemia-sao-paulo-vive-o-maior-apartheid-social-do-paisalerta-historiador/. Acesso em: 09 dez. 2020.

REZENDE, Constança. Número de militares em cargos civis mais que dobra em governo Bolsonaro. UOL, São Paulo, 17 jul. 2020. Disponível em: https://noticias.uol.com.br/colunas/constancarezende/2020/07/17/numero-de-militares-em-cargos-civis-mais-que-dobra-em-governobolsonaro.htm?cmpid=copiaecola. Acesso em: 09 dez. 2020.

SOPRANA, Paula. Preço do arroz pode subir ainda mais, diz associação de supermercados. Folha de São Paulo, São Paulo, 10 set. 2020. Disponível em: https://www1.folha.vol.com.br/mercado/2020/og/preco-do-arroz-pode-subir-ainda-maisdiz-associacao-de-supermercados.shtml. Acesso em: 10 dez. 2020.

THE NEW YORK TIMES. Covid world map: tracking the global outbreak. 23 sept. 2020. Disponível em: https://www.nytimes.com/interactive/2020/world/coronavirus-maps.html. Acesso em: $10 \mathrm{dez} .2020$.

TOLEDO, V. M. Las claves ocultas de la sostenibilidad: transformación cultural, conciencia de especie y poder social. La Situación del Mundo, Madrid, n. 2010, 2010. 


\section{Detalhes dos autores}

\section{Alvaro Idárraga}

Alvaro Idárraga. Engenheiro Agrônomo (Colômbia). Secretário Executivo da Red COMPARTE.. E-mail: alidarraga@yahoo.com

\section{Joaci de S. Cunha}

Advogado, doutor em História pela Universidade Federal da Bahia (UFBA), pós-doutor (2020) pelo Programa de Políticas Sociais e Cidadania da Universidade Católica do Salvador, assessor do Centro de Estudos e Ação Social (CEAS) e coeditor da revista Cadernos do CEAS. É autor de diversos artigos e capítulos publicados, respectivamente, em revistas e livros. Pela Edufuba (2017) assina O fazer político da Bahia na República (19001930). Matriz das relações entre Estado, corporações e políticos. E-mail: joacisc@gmail.com 